\title{
II-1 Processing and Secretion of Proteins in Prokaryotic Cells
}

\author{
Shoji Mizushima \\ Faculty of Agriculture, Nagoya University, Chikusa-ku, Nagoya 464, Japan
}

\section{Secretory apparatus}

A mutant of Bacillus subtilis that hyperproduces $\alpha$-amylase was isolated from tunicamycin resistant cells (Sasaki et al., 1976) and the chromosomal location was mapped (tmrA) (Nomura et al., 1978). Another mutation (pap or amyB) that induces heperproduction of $a$-amylase and protease also was reported (Sekiguchi, Takada and Okada, 1975; Yoneda and Maruo, 1975; Hitotsuyanagi et al., 1979). Although the genes responsible for these mutations probably are involved in the apparatus for protein export, the gene products remain unknown.

Ito et al. (1983) characterized a temperature sensitive $\sec Y$ mutation in Escherichia coli that was located in the $s p c$ ribosomal protein operon. This $t s$ mutation resulted in accumulation of secretory proteins having unprocessed signal sequences, suggesting that the product of the $\sec Y$ gene is a component of the cellular apparatus for protein export across the cytoplasmic membrane. Ito, Bassford and Beckwith (1981) also revealed that the apparatus for export of many proteins including those of the periplasm and outer membrane share a common step.

Characterization of precursors of secretory proteins

Many precursors having unprocessed signal sequences were found and characterized in E. coli. These are alkaline phosphatase (Kikuchi et al., 1981), the OmpF protein (Mutoh, Inokuchi and Mizushima, 1982), peptidoglycan-associated lipoprotein (PAL) and seven new lipoproteins (NLP1 to NLP7) (Ichihara, Hussain and Mizushima, 1981). The signal sequences of the OmpF protein and alkaline phosphatase were determined. Precursors of PAL and NLPs were found in forms modified with glyceride as mature proteins. The signal sequence of $a$-amylase of $B$. subtilis was also determined (Ohmura et al., 1983). A method to isolate a chemical quantity of the precursor of maltose binding protein was reported by Ito (1982).

Export of lipoproteins across the cytoplasmic membrane

The discovery of globomycin, which inhibits biosynthesis of the major lipoprotein (LP), by Inukai et al. (1978a, 1978b) stimulated studies on the mechanism of lipoprotein export. This drug resulted in the accumulation of glyceride-containing precursors of LP in the cytoplasmic membrane (Hussain, Ichihara and Mizushima, 1980), suggesting that the modification was a prerequisite for the signal peptide cleavage. From analyses of the orientation of the precursor in the cytoplasmic membrane it was concluded that export of the lipoprotein domain of the precursor can take place before the cleavage of the signal peptide that is most probably held in the cytoplasmic membrane (Ichihara, Hussain and Mizushima, 1982). PAL and NLPs also were suggested to be processed in the same manner. 


\section{Signal peptidase}

A temperature-sensitive mutant of the signal peptidase for LP was isolated by Yamagata et al. (1982). This mutant showed weak signal peptidase activity and was lethal when LP was overproduced. Using this mutant, a plasmid carrying the lipoprotein signal peptidase gene $(l s p A)$ was isolated (Yamagata, Daishima and Mizushima, 1983a). The $l s p A$ gene was mapped at $0.5 \mathrm{~min}$ in the $E$. coli chromosome (Yamagata et al., 1983b). Lipoprotein signal peptidase was first studied as membrane enzyme (Hussain, Ichihara and Mizushima, 1982a), then purified. The enzyme showed activity toward PAL and many NLPs as well as LP (Yamada, Yamagata and Mizushima, 1983).

Signal peptide peptidase

The enzyme responsible for digestion of the signal peptide that had been clipped off from LP was characterized by Hussain et al. (1982a, 1982b). The enzyme is inhibited by inhibitors of microbial origine such as antipain, leupeptin, chymostain and elastatinal.

\section{REFERENCES}

Hitotsuyanagi, K., Yamane, K. and Maruo, B. (1979). Agric. Biol. Chem. 43, 2324-2349.

Hussain, M., Ichihara, S. and Mizushima, S. (1980). J. Biol. Chem. 255, 3707-3712.

Hussain, M., Ichihara, S. and Mizushima, S. (1982a). J. Biol. Chem. 257, 5177-5182.

Hussain, M., Ozawa, Y., Ichihara, S. and Mizushima, S. (1982b). Eur. J. Biochem. 129, 233-239.

Ichihara, S., Hussain, M. and Mizushima, S. (1981). J. Biol. Chem. 256, 3125-3129.

IChihara, S., Hussain, M. and Mizushima, S. (1982). J. Biol. Chem. 257, 495-500.

Inukai, M., Nakajima, M., Ōsawa, M., Haneishi, T. and Arai, M. (1978a). J. Antibiot. 31, 421425.

Inukai, M., Takeuchi, M., Shimizu, K. and Arai, M. (1978b). J. Antibiot. 31, 1203-1205.

Ito, K. (1982). J. Biol. Chem. 257, 9895-9897.

Ito, K., BASSFOrd, JR., P. J. and BeCKWITh, J. (1981). Cell . 24, 707-717.

Ito, K., Wittekind, M., Nomura, M., Shiba, K., Yura, T., Miura, A. and Nashimoto, H. (1983). Cell 32, 789-797.

Kikuchi, Y., Yoda, K., Yamasaki, M. and Tamura, G. (1981). Agri. Biol. Chem. 45, 2401-2402.

Mutoh, N., Inokuchi, K. and Mizushima, S. (1982). FEBS Letters 137, 171-174.

Nomura, S., Yamane, K., Sasaki, T., Yamasaki, M., Tamura, G. and Maruo, B. (1978). $J$. Bacteriol. 136, 818-821.

Ohmura, K., Yamazaki, H., Takeichi, Y., Nakayama, A., Otozai, K., Yamane, K., Yamasaki, M. and Tamura, G. (1983). Biochem. Biophys. Res. Comm. 112, 678-683.

Sasaki, T., Yamasaki, M., Maruo, B., Yoneda, Y., Yamane, K., Takatsuki, A. and Tamura, G. (1976). Biochem. Biophys. Res. Comm. 70, 125-131.

Sekiguchi, J., TaKada, N. and OKada, H. (1975). J. Bacteriol. 121, 688-694.

Yamada, H., Yamagata, H. and Mizushima, S. (1983). FEBS Letters 166, 179-182.

Yamagata, H., Ippolito, C., Inukai, M. and Inouye, M. (1982). J. Bacteriol. 152, 1163-1168.

Yamagata, H., Daishima, K. and Mizushima, S. (1983a). FEBS Letters 158, 301-304.

Yamagata, H., Taguchi, N., Daishima, K. and Mizushima, S. (1983b). Molec. Gen. Genet. 192, $10-14$.

Yoneda, Y. and Maruo, B. (1975). J. Bacteriol. 124, 48-54. 